\title{
Yoğun Bakım Hastalarında Hipertansiyon
}

\section{Hypertension in Intensive Care Unit Patients.}

\author{
IIhan Kurultak', Reyhan Calayoğlư ${ }^{2}$
}

1 Nefroloji Bilim Dalı, Tıp Fakültesi, Trakya Üniversitesi, Edirne, Türkiye 2 Nefroloji Kliniği, Sadi Konuk Eğitim ve Araştırma Hastanesi, İstanbul, Türkiye

\section{ÖZET}

Hipertansiyon normal popülasyonda olduğu gibi, yoğun bakım hastalarında da sık karşılaşılan önemli bir problemdir. Ancak hipertansiyonla ilgili şu ana kadar literatürde oluşmuş bilgi birikimi daha ziyade ayaktan takip edilen kardiyovasküler riski orta ve yüksek olan hasta gruplarında yoğunlaşmış, yoğun bakım hastalarında sınırlı kalmıştır. Yaşamı tehdit eden öncelikli sorunların çözümü için uğraşan sağlık ekibi tarafından hipertansiyonun istemsiz göz ardı edilmesi, takip edilen her hastanın bireysel özelliklerinin ve medikal destek ihtiyaçlarının çeşitliliğ bu duruma yol açıyor olabilir. Bu zorluklara rağmen yoğun bakımda çalışan klinisyenden birçok konuda olduğu gibi hipertansiyonun yönetimi konusunda da doğru olanı eksiksiz yapması beklenmektedir. Bu derlemede eldeki veriler ışı̆̆ında yoğun bakım hastalarında hipertansiyonun değerlendirilmesi ve tedavisi irdelenmiştir.

Anahtar Kelimeler: Hipertansiyon, Yoğun Bakım Ünitesi, Erişkin Hasta

\section{ABSTRACT}

Arterial hypertension, also has higher incidence in normal population, is a common problem in intensive care unit (ICU). However the data regarding HT are particularly about the outpatients, who have variety of cardiovascular risks and it had remained limited in ICU patients. The ignoring of HT involuntary by health professionals who fight with the more complicated life threatening problems, the existence of different medical conditions of patients and variety of each individual needs can lead this situation. Despite of these difficulties, it is expected that the clinician should be successful to do correct action completely in management of HT like in a lot of the other medical conditions. In this review, the evaluation and treatment of HT in ICU is examined in light of recent data.

Key Words:Hypertension, Intensive Care Unit, Adult
Corresponding Author: Illhan Kurultak

Address: Trakya Üniversitesi Tıp Fakültesi, Nefroloji Bilim Dalı, Edirne

E-mail: ilhankurultak@yahoo.co.uk
Başvuru Tarihi/Received: 04-05-2015

Kabul Tarihi/Accepted: 04-06-2015 


\section{Giriş̧}

Hipertansiyon normal popülasyonda olduğu gibi, yoğun bakım hastalarında da sık karşılaşılan önemli bir problemdir. Ancak hipertansiyonla ilgili şu ana kadar literatürde oluşmuş bilgi birikimi daha ziyade ayaktan takip edilen kardiyovasküler riski orta ve yüksek olan hasta gruplarında yoğunlaşmış, yoğun bakım hastalarında sınırlı kalmıştır. Yaşamı tehdit eden öncelikli sorunların çözümü için uğraşan sağıı ekibi tarafından hipertansiyonun istemsiz göz ardı edilmesi, takip edilen her hastanın bireysel özelliklerinin ve medikal destek intiyaçlarının çeşitliliği bu duruma yol açıyor olabilir. Bu zorluklara rağmen yoğun bakımda çalışan klinisyenden birçok konuda olduğu gibi hipertansiyonun yönetimi konusunda da doğru olanı eksiksiz yapması beklenmektedir. Bu derlemede eldeki veriler ışığında yoğun bakım hastalarında hipertansiyonun değerlendirilmesi ve tedavisi irdelenmiştir.

\section{TANIM}

Uluslararası kabul edilirliği yüksek son HT kılavuzlarında (JNC The Joint National Committee, ESH/ESC European Societies of Hypertension and Cardiology, NICE National Institute for Health and Clinical Exellence, CHEP Canadian Hypertension Education Programme) her ne kadar yaşlı hastalarda HT tanımı ve tedavi hedeflerinde bazı tartışmalar olsa da 18 yaş üstü popülasyonda HT tanısı için eşik değer 140/90 mmHg olmaya devam etmektedir (1-4). Bu veriler ışığında Mayıs 2015'de Türkiye'de önde gelen 5 bilimsel topluluğun ortaklaşa hazırlayıp sunduğu Türk HT Uzlaşı Raporu'na göre arteriyal kan basıncı eşik değerleri şu şekildedir (5);

Normal KB: Sistolik $<130 \mathrm{mmHg}$ ve diastolik $<85 \mathrm{mmHg}$

Prehipertansiyon: Sistolik 130-139 mmHg ve diastolik 85-89 mmHg

Hipertansiyon: Stage 1: Sistolik 140-159 $\mathrm{mmHg}$ ve diastolik $89-99 \mathrm{mmHg}$

Stage 2: Sistolik 160-179 mmHg ve diastolik 100-109 mmHg

Stage 3: Sistolik $\geq 180 \mathrm{mmHg}$ ve diastolik $\geq 110$ $\mathrm{mmHg}$

Ek olarak sistolik/diastolik $\geq 140 /<90 \mathrm{mmHg}$ durumunda izole sitolik HT olarak tanımlanmaktadır. Bunlara ek olarak 80 yaş üstü hastalarda sistolik HT sınırının 150 mmHg olabileceği uzman görüşü olarak vurgulanmıştır. Bu tanımlamaların dışında şiddetli HT başlığı altında bulunan hipertansif acil (emergency), hipertansif öncelikli durum (urgency), akselere HT ve malign HT gibi farklı terimler klinisyenler tarafından kullanılmaktadır.

Siddetli(severe) HT: Kan basıncının sistolik $\geq 180 \mathrm{mmHg}$ ve/veya diastolik $\geq 120 \mathrm{mmHg}$ nin üzerinde olması olarak tanımlanır.

Akselere-Malign HT: Şiddetli HT ile birlikte olan göz dibi bulgularının varlığı (grade 3 ise akselere; grade 4 ise malign) saptandığında ensefalopati eşlik etsin ya da etmesin tanı konur. Akselere $\mathrm{HT}$, malign $\mathrm{HT}$ terimlerinin ayrımı ve bu ayrımın klinik anlamı net değildir (6). Bu nedenle artık tek başına kullanımları tercih edilmemektedir.

Hipertansif öncelikli Durum(urgency): Şiddetli HT ile birlikte herhangi bir semptom veya uç organ hasarının bulunmaması durumudur.

Hipertansif acil (emergency): Şiddetli HT’a uç organ hasarlarının eşlik etmesi olarak tanımlanır (Tablo 1) (22).

\section{EPIDEMIYOLOJi}

$A B D$ de NHANES "National Health and Nutrition Examination Survey" 2005-2008 verilerine göre yetişkin populasyonunda HT sıklığı \%29-31 olarak tespit edilmiştir (7). Türkiye'de PATENT çalışmasında da bu oran benzer şekilde \%31.8'dir (8). Yani erişkin nüfusun yaklaşık üçte biri hipertansifdir. Bu hastaların HT acilleri ile yaşamları boyunca en az bir kez karşılaşma olasılıklarının \%1-2 olduğu düşünülürse, $\mathrm{HT}^{\prime}$ un sağlık sistemine ve YBÜ'lerine getirdiği ağır yük görülür (9). Yapılan bir çalışmada HT merkezine dirençli HT tanısı ile refere edilen hastaların \%0.9'unun YB ünitesinde (YBÜ) izlem ihtiyacı olduğu raporlanmıştır (10). YBÜ'de takip edilmekte olan hastalarda HT görülme sıklığı ile ilgili net bir veri yoktur ancak ciddi $\mathrm{HT}^{\prime}$ un sık olduğu düşünülmektedir (11). Literatürde farklı hasta gruplarında çalışmalar mevcuttur. Cerrahi operasyonlar sonrası YBÜ'nde gelişen postoperatif HT sıklığı \%4-35 olarak saptanmıştır (11-13). Özellikle koroner ar- 
ter by-pass operasyonları, aort ve karotis gibi büyük damarların klemplenmesine ihtiyaç duyulan hastalarda hipertansif kriz çok daha sıktır (14). Yine gebelik ilişkili hipertansiyon (pre-eklamsi) vakaları tüm gebeliklerin \%3-7'sinde ortaya çıkar. Bunların bir kısmı ciddi (>160/110 mmhg) $H T$, eklamsi ve uç organ hasarının eşlik ettiği YBÜ intiyacı doğuran tablolardır (15-17).

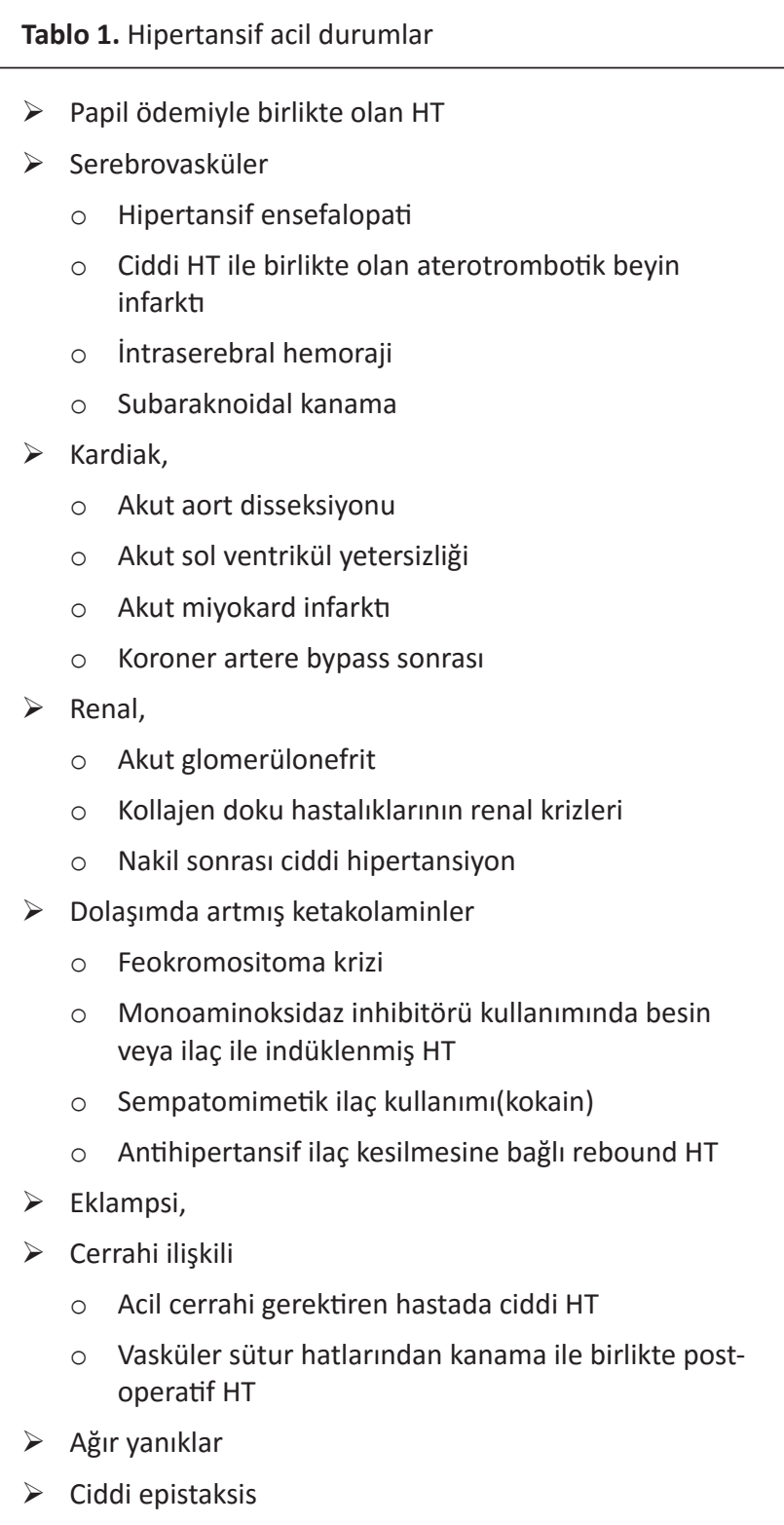

\section{PATOFizYOLOJi}

Sağlıklı bir bireyde arteriyel kan basıncı (AKB); kardiyak debi (KD) ve periferik vasküler direnç (PVD) katkılarıyla oluşturulur. Şu şekilde formülize edilir.

$$
A K B=K D X P V D
$$

Kalp debisi, kalp hızı ve stroke volümden direkt olarak etkilenmektedir. Bu eşitliğin sağındaki parametrelerin her birinin değişimine neden olan faktörler AKB'nda değişikliklere ve otoregülasyonun devreye girmesine neden olur. Örneğin artmış intravasküler volüm ve/veya sempatik aktivite, artmış kalp debisine ve AKB yükselmesine neden olur. Bu durumda barorefleks mekanizma saniyeler içinde devreye girer ve periferik vasküler direnç azaltılmaya çalışılır. Bu kompanzasyona nöro-endokrinolojik (endotel kaynaklı vazoaktif maddeler, NO, Endotelin, büyük damarlarda bulunan basınç sensörleri ve bu sensörlerden alınan bilgilerin işlendiği santral merkezler, beyin sapı ve hipotalamus vs) sistemler dakikalar ve saatler içerisinde katkıda bulunur. Böylece doku perfüzyonu için gerekli fizyolojik AKB düzeylerinin sabit sınırlarda kalması sağlanır. Uzun dönemdeki $A K B$, böbreklerin merkez rol oynadığı karmaşık mekanizmalar (özellikle renin-angiotensin-aldosteron aksı ve renal tuz tutulumunu etkileyen faktörler) ile regüle edilir (19). Tüm basamakların herhangi bir kısmında oluşan edinsel veya kalıtsal değişikler $\mathrm{HT}^{\prime}$ un gelişiminde farklı derecelerde rol oynar.

\section{YBÜ'NDE HT ILE KABUL EDILEN HASTALARDA ETIYOPATOGENEZ}

Semptomsuz ciddi hipertansiyon(urgency) esansiyel $\mathrm{HT}^{\prime}$ un yetersiz tedavi ve takip edildiği hastalarda ve ikincil HT'un yavaş gelişen formlarında sıktır. Bu hastalarda genellikle arteriyel sistemin kompansatris değişiklerine (remodeling, kardiyovasküler sistemde hipertrofi vs.) izin veren kronik bir süreç vardır. Bu durumda kan basıncının arteriyel sistemden kapiller sisteme ulaşması kısmı olarak engellenir ve genellikle bu hastalar akut uç organ bulguları ile başvurmazlar. Ancak sistolik $\geq 180 \mathrm{mmHg}$ ve/veya diastolik $\geq 120 \mathrm{mmHg}$ durumunun uzun süre sebat etmesi veya bu değerlerin altında kalsa dahi kan basıncının kısa sürede yükselmesi; başta beyin, kalp ve böbrek olmak üzere birçok organda kompansatris mekanizmalarının devre dışı kalmasına, akut ve kronik bulgulara neden olabilir(2).

Hipertansif acil durum (emergency) altta yatan esansiyel veya ikincil hipertansiyonun komp- 
likasyonu olarak ya da yeni başlayan bir durum olarak ortaya çıkabilir. Hipertansif krizlerde, uç organ hasarı ile sonuçlanan kaskadın tetiklenmesi için sistemik vasküler dirençte ani bir artışın gerekli olduğu görülmektedir. AKB'nın ani ve ciddi bir şekilde yükselmesine neden olan faktörlerin bir kısmı bilinse de halen birçoğu net değildir $(20,21)$. Endotelin kan basıncı regülasyonunda birçok vazoaktif madde ile aktif rol oynadığı bilinmektedir. Nitrik oksit (NO) ve prostasiklin gibi vazodilatör maddeler, ani yükselen kan basıncına bağlı gelişen mekanik strese (shear stres) maruz kalan endotelden salgılanarak vasküler direncin daha fazla artmasına engel olur (norepinefrin, asetil kolin ve substans $P$ gibi endotelyal agonistler de bu maddelerin salınımını uyarır). Ancak yarılanma ömrü çok kısa olan bu maddeler uzamış yüksek AKB durumunda etkinliğini kaybeder, endotelyal kompansatris vazodilatör cevap yetersiz kalır ve "shear stres" endotel hasarına neden olur. Ek olarak vasküler geçirgenliği arttırarak fibrinoid meteryalin damar duvarında birikimine neden olur. Bu durum pıhtılaşma faktörlerini ve trombositleri pıhtılaşma leyhine etkinleştirebilir. Kan basıncının yüksek olarak devam etmesi ile endotel hasarı ağırlaşır ve arteriollerde fibrinoid nekroz gelişir $(9,20-22)$. Bu süreç doku iskemisine ve daha fazla vazoaktif medyatörün salınmasına neden olarak kısır döngüye yol açar. Aktive olan renin anjiyotensin sistemi de vazokonstriksiyonun artmasına ve proinflamatuvar sitokinlerin salınımına neden olur. Basınç natriürezi sonucu oluşan hacim kaybı böbreklerden daha fazla vazokonstriktör salınımına yol açar. Bu kollektif mekanizmalar uç organ hipoperfüzyonu, iskemi ve fonksiyon bozukluğu ile sonuçlanır; bu durum karşımıza hipertansif acil olarak çıkar $(20,22)$. Hipertansif acil gelişiminde kan basıncının ciddi düzeylere yükselme hızının da önemli olduğu bilinmektedir. Zeminde yatan hastalık (akut glomerulonefrit, preeklamsi-eklamsi vs) nedeniyle saatler ve günler içerisinde gelişen $\mathrm{HT}^{\prime}$ unun kan basıncı değerlerinden bağımsız olarak uç organ hasarı yaratabileceği unutulmamalıdır. Tablo 2 de olası etiyolojiler sunulmuştur (22).
Tablo 2. Hipertansif acillere yol açabilecek hastalıklar.

$>$ Esansiyel hipertansiyon (kontrolsüz, yeni tanı)

$>$ Renal parankimal hastalık

○ Akut glomerülonefrit

○ Vaskülit

- Hemolitik üremik sendrom

- Trombotik trombositopenik purpura

- Skleroderma renal krizi

Renovasküler hastalık

- Renal arter stenozu (ateromatöz veya fibromusküler)

$>$ Gebelik

- Preeklampsi-eklamsi

$>$ Endokrin hastalıklar

- Feokromasitoma

○ Cushing sendromu

○ Renin salgılayan tümörler

- Mineralokortikoid hipertansiyonu

$>\quad$ ilaçlar

- Kokain,

- Sempatomimetikler

- Eritropoetin

○ Siklosporin

- Antihipertansif medikasyonun kullanılmaması

- Monoamino oksidaz inhibitörleriyle etkileşim (tiramin)

- Amfetaminler

- Kurşun zehirlenmesi

> Otonom hiperreaktivite

- Guillain-Barre sendromu

- Akut intermittan porfiri

Santral sinir sistemi hastalıkları

- Kafa travması

- Serebral infarkt/kanama

○ Beyin tümörleri

\section{YBÜ'DE YENI GELIŞEN HIPERTANSIYYNDA ETIYOPATOGENEZ}

Bu hasta grubu doktor liderliğindeki sağlık ekibinin sürekli müşahadesi altındadır ve çoğu zaman bu izlemde yardımcı cihazlar (intra-arteriyal kan basıncı takibi, monitorizasyon vb.) kullanılır. Cihazın ve deneyimsiz sağlık personelinin tespit ettiği tüm beklenmeyen klinik bulgular gibi yüksek saptanan AKB ölçümünün de daha önce hipertansif olmayan hastada teyit edilmesi 
önemlidir. YBÜ’ne kabul edilmiş hasta grubunda yeni saptanan $\mathrm{HT}$, nedenleri açısından ayaktan başvuran hastalardan farklılıklar gösterir (11).

\section{Klinik değerlendirme:}

YBÜ de değerlendirilen ciddi AKB yüksekliği (Sistolik $\geq 180 \mathrm{mmHg}$ ve/veya diastolik $\geq 120$ $\mathrm{mmHg}$ ) olan hasta ister yeni gelişen isterse önceden varolan $\mathrm{HT}^{\prime} \mathrm{u}$ bulunsun süratle uç organ hasarı bulguları açısından değerlendirilmelidir. Bu cümleden bu rakamlardan daha düşük (sistolik 140-179 mmHg ve/veya diastolik 90-119) AKB yüksekliklerinde uç organ hasarı olmaz yargıSı çıkartılmamalıdır. AKB'ının hızlı yükselmesi ve/veya kompanzasyon mekanizmaların yetersiz kalması sonucunda $\mathrm{mmHg}$ değerinden bağımsız olarak komplikasyonlar gelişebilir. Yani $\mathrm{HT}^{\prime}$ unun "rakamsal derecesi" yanında "hastadaki sonuçları" değerlendirilmeli, komplikasyonları titizlikle aranmalı ve süratle klasifiye edilmelidir. Bu amaca yönelik olarak anamnez ve ayrıntılı fizik muayene klinisyene önemli ipuçları verir. Öykü de bilinç değişiklikleri (hipertansif ensefalopati), görme bozuklukları, göğüs ağrısı (miyokard iskemisi, infarktüsü, aort diseksiyonu), sırt ağrısı (aort diseksiyonu), dispne (pulmoner ödem veya konjestif kalp yetmezliği), epileptik nöbet gibi semptomların bulunması hastanın hipertansif acil durum olabileceğinin önemli göstergeleridir. FM de periferik arterlerin karşılaştırmalı palpasyonu yapılmalı, büyük damar traseleri boyunca oskültasyon uygulanmalı, AKB her iki koldan (önemli farklar büyük arter patolojilerini destekler) hem yatar hem oturur pozisyonda (hipovolemi tespiti amacıyla) ölçülmelidir. Yapılabilirse fundoskopik inceleme (yeni hemoraji, eksüda, papil ödemi acil hipertansiyonu telkin eder) hipertansif göz komplikasyonlarını ortaya çıkarabilir. Kalp incelemesi yetmezliğin olup olmadığını aydınlatmaya yönelik olmalıdır (juguler venöz basınçda artma, raller, S3). Nörolojik inceleme bilateral pupil genişliği ve reflekslerine, şuur durumuna, meningeal irritasyon bulgularına, görme alanına ve fokal nörolojik bulgulara odaklanmalıdır. Süratle yapılacak laboratuvar incelemeleri ürik asit, lipidler, laktat dehidrogenaz, elektrolitler, üre, serum kreatinin, tam kan sayımı (periferik yayma hemoliz yönünden şistositleri görmek amacıyla), tam idrar tetkiki, elektrokardiyografi, PA akciğer grafisi olmalıdır. Sıklıkla diyastolik kan basıncının ısrarla $\geq 120 \mathrm{mmHg}$ olması acil parenteral ilaç tedavisi gerektirebilecektir. Ancak klinik tablonun gelişmesinde daha önce de belirtildiği gibi mutlak kan basıncı değerinden ziyade bu değere çıkış hızı daha fazla önem taşımaktadır $(9,20)$.

Yoğun bakım ünitesinde ciddi AKB (Sistolik $\geq 180 \mathrm{mmHg}$ ve/veya diastolik $\geq 120 \mathrm{mmHg}$ ) yüksekliği olup uç organ hasarı olsun veya olmasın tüm hastalar öncelikle tetikleyici faktörler açısından irdelenmelidir. Emosyonel stres, ağrı, anestezik ilaçların kesilmesi, üriner retansiyon, hiperkapni, hipoglisemi, asidoz, hipoksemi ve buna bağlı anksiyete, uygun olmayan sıvı tedavileri, önceki antihipertansif ilaçlarının kesilmesi gibi durumlar vakit kaybetmeden düzeltilmelidir. Bu şekilde AKB kontrol altına alınan hastalar geçici (transitory) ciddi HT olarak değerlendirilirler (11). Başarılı müdahaleye rağmen gerilemeyen ve uç organ hasarı bulguları olan hipertansif acil (emergency) hastalar klinik durumlarının özelliklerine uygun olan iv tedavilerle ivedilikle tedavi edilmelidir. Uç organ hasarı ve semptomu bulunmayan AKB değerleri sebat eden hastalar sürekli (permanent) ciddi HT olarak değerlendirilirler ve hipertansif öncelikli durum(urgency) gibi tedavi edilirler (11). AKB değerleri güvenli sınırlara çekilen hastalar daha detaylı değerlendirilmeli, önceden var olan $\mathrm{HT}^{\prime}$ un neden olduğu uç organ hasarı, YBÜ'ne kabulden önce kullanılmakta olan antihipertansif tedavi detayları, bu tedaviyle HT'un kontrol altında olup olmadığı, reçete edilmeden kullanılabilen preparatlar (sempatomimetikler gibi), illegal ilaç kullanımı (kokain gibi) açısından sorgulanmalıdır $(9,11,18)$. Daha geniş zaman aralığında yapılan bu değerlendirmeler sonucunda HT'un uzun dönem tedavisi planlanmalıdır.

YBÜ'ne HT dışı nedenlerle yatırılmış, uç organ hasarı bulgu ve semptomları olmayan hastalardaki AKB değerlerinin (sistolik 140-179/ diastolik 90-119 mmHg) klinik anlamı net değildir. Yukarıda detaylı olarak bahsedilen tetikleyici faktörler ve medikal öykü gözden geçirilmeli, HT öyküsü saptanan hastalara bireysel özelliklerine göre uygun diyet ve oral antihipertansif tedavisi başlanmalıdır. 


\section{TEDAVi}

\section{Genel yaklaşım}

"Hipertansif öncelikli durum" (urgency, permanent), "hipertansif acil durum" (emergency) olarak ayırt edilmiş hastalarda tedavi planı yapılabilir. Bu ayırım önemlidir çünkü seçilecek ilaçlar, uygulama yolu, AKB'nın düşürülme hızı ve tedavi hedefleri bu ayrıma göre ciddi farklıIıklar içerir. Hipertansif öncelikli durum (urgency, permanent)'larda hangi hastanın, AKB'ının ne hızda düşürüleceği ve erken dönemde tedavinin rakamsal hedefleri net değildir. Önceleri kullanılan ancak şu an önerilmeyen dilaltı nifedipin uygulaması sonrası edinilen bilgiler AKB'nın hızlı düşürülmesi ve daha düşük tedavi hedeflerinin belirlenmesinin hayati organlarda ciddi iskemik olayları tetikleyebileceğini göstermiştir (26). Bu nedenle tedavinin birinci saati sonunda başlangıç TA değerinden \%25 den daha fazla olan düşüşün hastaya zarar verebileceği bilinmelidir(2-26). Genel amaç hastanın AKB'ını daha güvenli sınırlara(<160/100) "saatler ve günler" içerisinde çekilmesinin sağlanmasıdır (1,21-26). Uzun dönemde tedavi hedefleri daha nettir ve tedavi hastada HT'a eşlik eden faktörleri de göz önüne alınarak belirlenir.

Hipertansif acil durum (emergency) tanısı almış hastalarda yakın ve doğru AKB takibi için süratle intrarteriyal yol açılmalı ve kan basıncı monitorizasyonu sağlanmalıdır. Bu hasta grubunda tedavi planı hastanın özelliklerine göre seçilen iv preperatlarla yapılmalıdır. Genel amaç total azalmanın başlangıç değerinin \%25 inden fazla olmaması şartıyla diastolik kan basıncının 100-105 mmHg seviyelerine 2-6 saatte indirilmesidir(21-23). Aort disseksiyonu genellemenin dışındadır çünkü bu hastalarda AKB'ının dakikalar içerisinde düşürülmesi ek yararlar sağlayabilir(27). Aşağıda bu amaçlarla kullanılan ilaçlar ve kullanımlarının uygun olduğu klinik durumlar irdelenmiştir.

\section{Serebrovaskuler Olaylar}

İskemik inmede özellikle ilk gün olmak üzere en az bir hafta ani kan basıncı düşmelerinden sakınmak iskemik beyin dokusunun perfüzyo- nunun bozulmaması için gereklidir. Son kılavuz revizyonunda spesifik bir kan basıncı hedefi belirlenmemiştir ancak SKB >220 veya DKB >105 $\mathrm{mmHg}$ üzerindeki değerlerde hemorajik komplikasyonun arttığı vurgulanmıştır (28). Bu nedenle kan basıncı >220/120 mmHg veya uç organ tutulumu varlığında $>200 / 100 \mathrm{mmHg}$ ise tedavi uygun olur. Trombolitik tedavi yapılacak ise tedavi hedefleri sistolik kan basıncı (SKB) $\leq 185 \mathrm{mmHg}$, diastolik kan basıncı(DKB) $\leq 110 \mathrm{mmHg}$ olmalıdır $(29,30)$

Intraserebral hemorajiye bağlı inmede sistolik kan basıncı 220-150 mmHg arasında olan hastalarda 1 saat içinde $140 \mathrm{mmhg}$ altına indirmenin, hızlı düşürmenin kontrendike olmadığı durumlarda, güvenli olduğu düşünülmektedir. SKB $>220 \mathrm{mmHg}$ olanlarda ise kanıtlar daha zayıf olsa da sık (5 dk da bir) monitörizasyon ile AKB kontrollü bir şekilde düşürülmelidir (31). İntrakranial basınç artışı(IKB) bulguları olan hastalarda mümkünse İKB monitorize edilmeli ve serebral perfüzyon basıncı(SPB) $60 \mathrm{mmHg}$ üzerinde tutulmalıdır. ( $\mathrm{SPB}=\mathrm{OAB}-\mathrm{iKB}, \mathrm{OAB}=\mathrm{DKB}+\mathrm{SKB}-\mathrm{DKB} / 3$ ) Bu hastalarda kan basıncı hedefi ilk 6 saat içinde 160/90 mmHg ve OAB da $110 \mathrm{mmHg}$ dır (32).

Subaraknoidal kanamalarda HT tedavisinde akut dönemde hedef kan basıncı konusu tartışmalıdır. Ancak SPB'nın $\geq 70 \mathrm{mmHg}$ tutulmasının uygun olacağı düşünülür. Bir çalışmada $\mathrm{DKB}<100$ $\mathrm{mmHg}$ olacak şekilde tedavi edilen hastalarda tekrar kanama riski azalırken serebral iskemi oranı yüksek bulunmuştur (33). Bu hasta grubunda ventrikülostomi ile IKK yakın takip etmek, SPB'nı bozmayacak en düşük $A K B$ düzeylerinde hastayı izlemek mantıklı görünmektedir (34).

\section{Aort Disseksiyonu}

$\mathrm{Bu}$ hasta grubunda AKB'nın dakikalar içerisinde düşürülmesi hayati önem arz eder. İvedilikle kalp atım hızının 60/dk'nın altına çekilmesi, AKB'nın 100-120 mmHg veya daha aşağılara çekilmesi (hipotansiyona bağlı iskemik organ bulguları yoksa) uygun olur. Tedaviye öncelikle beta bloker ajan ile başlanmalı daha sonra periferik arterlere etkili ilaçlar(sodyum nitroprussid) tercih edilmelidir (refleks taşikardiyi engellemek amacıyla) (27). 


\section{Akut Koroner Olaylar}

Sol ventrikül disfonksiyonu $(\mathrm{EF}<\% 40)$ ile beraber olan koroner olaylarda genellikle pulmoner konjesyon tabloya eşlik eder. Öncelikli seçilecek ilaç nitrogliserin ve furosemid kombinasyonudur. Bu hastalarda tedavi SKB 110 mmHg'nın altına inmeyecek veya başlangıçta saptanan değerin \%25'den daha fazla düşüş olmayacak şekilde sağlanmalıdır. Sildenafil ve benzeri ilaç kullanımının tespitinde, SKB $90 \mathrm{mmHg}$ 'nin altında veya ilk aşamada $30 \mathrm{mmHg}$ aşan hızlı düşüşlerde nitratlar kullanılmamalıdır. YBÜ'e kabulde göğüs ağrısı ve ölüm korkusu nedeniyle ciddi anksiyetesi olan hastalar morfin sülfat kullanımından yarar görebilir (35).

\section{Malign HT ve Hipertansif Ensefalopati}

AKB'ndaki total redüksiyonun başlangıç değerinin \%25 inden fazla olmaması şartıyla diastolik kan basıncının 100-105 mmHg seviyelerine 2-6 saatte indirilmesi uygun bir yaklaşımdır. Daha hızlı düşüşler iskemik inmeye neden olabillir. Bu amaçla Ca kanal blokerleri (nikardipin, clevidipin), labetolol ve nitroprussid kullanılabilir (18, $22,36)$.

\section{Gebelik HT}

Gebelerde ciddi HT tanımı AKB $\geq 160 / 110$ $\mathrm{mmHg}$ olduğu durumlar için kullanılmaktadır. Bu hastalarda HT yönetimi fetus için hayati önemi olan plesental akımı azaltmayacak ve anneyi HT komplikasyonlarından koruyacak şekilde yapılmalıdır. Tedavi sınırları net değildir ancak uç organ hasarı olmayan gebelerde tedavi hedefi 140-150/ 90-100 mmHg arasında olmalıdır. Uç organ hasarı olan hastalarda bu hedef değerler 120-140/80-90 mm Hg olacak şekilde azaltılabilir. Daha fazla düşüşler plasental kan akımını azaltabilir $(37,38)$. Ancak $A K B \geq 180 / 120 \mathrm{mmHg}$ olan belirgin ciddi HT olan eklamptik gebelerde DKB 105-110 mmHg olan değerlere 2-6 saatte indirilmelidir. Başlangıç değerinin \%25'inden daha fazla olan ani düşüşler önerilmez. Bu amaçla en çok kullanılan iki ilaç iv hidralazin ve labetelol'dür $(39,40)$. Nikardipinin de bu hasta grubunda tercih edilebileceğine dair kanıtlar vardır. Ancak bu ilaçlar ülkemizde ulaşılabilir değildir. Ülkemizde oral nifedipin en sık kullanılan preperattır. Bu ilacın dilaltı veya sıvı şeklinin kullanımı öngörülemeyen ani düşüşlere neden olduğundan önerilmemektedir. Kronik dönemde alfa metil dopa, nifedipin tercih edilir. Gebelikte HT yönetiminde kontrendike olan iki ilaç nitroprussid ve ACEI/ ARB'lerdir(40).

\section{HT İlaçların Aniden Kesilmesi}

Kısa etkili sempatik blokaj yapan ilaçlardan propronol ve klonidin gibi ilaçların aniden kesilmesi up-regulasyona uğramış koroner sempatik reseptörler aracılığıyla kardiyak iskemiye neden olabilir. Kan basıncı kontrolü için kesilen ilacın tekrar başlanması ve HT kontrol altına alındıktan sonra kademeli olarak kesilmesi uygun olur(41,42).

\section{Sempatik Aktivitede Ani Artış}

Bazı durumlarda artmış sempatik aktiviteye bağIı ciddi HT gelişebilir. Feokromasitoma, Guillain-Barre sendromu veya post-spinal kord yaralanmalarında gelişen otonomik disfonksiyonda, sempatomimetik ilaç kullanımında (kokain, amfetamin, fensiklidin, fenilproponalamin vs.) ve MAO (mono amin oksidaz) inhibitörlerinin kullanımında tiramin içeren gıdaların tüketilmesi ani ciddi hipertansif krize neden olabilir. Bu hastalarda HT kontrolü için kullanılacak antihipertansifler fentolamin ve nitroprussid'tir. Beta bloker tedavisi periferik alfa blokajından sonra uygulanmalıdır. $(7,8)$

\section{Spesifik İlaç Kullanımı}

\section{Nitrogliserin}

Hem arterioller hem de venler üzerinde dilatasyon etkisi gösterir ancak venöz sisteme olan etkisi daha belirgindir. Etkisi çok çabuk başlar, yarı ömrü 4 dakikadır. Karaciğer tarafından metabolize edilir. Kalp debisi genellikle etkilenmez, ancak az miktarda düşebilir. $5 \mathrm{mcg} / \mathrm{kg} / \mathrm{dk}$ iv. infüzyona başlanır, 5 dakikada bir $5 \mathrm{mcg} / \mathrm{dk}$ artırılarak 100 mcg/kg/dk doza kadar çıkılabilir. En sık yan etkisi baş ağrısıdır, tedaviyi kesmeyi gerektirebilir. Nitrogliserinin en sık kullanım alanı miyokardiyal iskemidir. Koroner dilatasyon etkisi 
nitroprussidden daha iyidir, koroner çalma sendromuna neden olmaz. Bu özelliklerinden dolayı koroner olaylarda, akciğer ödemi ve eşlik eden HT'da kullanılır (46).

\section{Nitroprussid}

Sodium nitroprussid güçlü arterial ve venöz dilatör etkisiyle, art ve ön yükü azaltır. Etkisi saniyeler içinde başlar, 1-2 dakika sürer ve plazma yarı ömrü 3-4 dakikadır. $0,25 \mathrm{mcg} / \mathrm{kg} / \mathrm{dk}$ iv infüzyonla başlanılarak hedef AKB değerlerine ulaşılana kadar $10 \mathrm{mcg} / \mathrm{kg} / \mathrm{dk}$ doza kadar artırılabilir. Çok çabuk yıkılması ve ışığa duyarlı olması nedeniyle hazırlanan ilacın 24 saat içinde kullanılması ve ışıktan korunması (alüminyum folyo kullanılabilir) gerekmektedir. İstenmeyen etkileri de vardır. Serebral kan akımını azaltıp kafa içi basıncını arttırabilir. Koroner arter hastalığı varlığında kardiyak kan akımını belirgin olarak (koroner çalma sendromu) düşürebilir. Akut miyokardiyal infarktüsün erken saatlerinde verilmesi mortalite oranını artırabilir $(9,46,47)$.

Sodyum nitroprussid kaynaklı siyanür karaciğerde tiyosiyanata metabolize edilir ve böbreklerden yavaş atılır. Siyanür tiyosiyanattan 100 kat daha toksiktir. Siyanür ile zehirlenme kardiyak arreste, komaya, ensefalopatiye, konvülziyona ve geri dönüşümsüz nörolojik bozukluklara neden olabilir $(9,46-48)$. Bu nedenle karaciğer ve böbrek fonksiyonları bozuk olan hastalarda kullanılması uygun değildir.

\section{Labetolol}

Labetolol selektif alfa 1 bloker ve nonselektif beta bloker etkilerini birlikte gösterir. Beta bloker etkisi 8 katı daha fazladır. Karaciğerde metabolize olduğu için böbrek yetmezliği olan hastalarda kullanımı güvenlidir. Etkisi 2-5 dakikada başlar, 5-15 dakikada zirve yapar ve 2-8 saatte azalarak sona erer. SKB ve PVR'ı azaltır. Kardiyak debi hafifçe düşer veya değişmez, serebral kan akımı, böbrek kan akımı ve glomerular filtrasyon oranı değişmez. Astımı veya Kronik Obstrüktif Akciğer (KOAH) hastalığı olan kişilerde dikkatli kullanılmalıdır. Refleks taşikardi yapmadığı ve serebral kan akımını azaltmadığı için serebrovasküler hastalıklarda ve koroner arter hastalıklarında kullanılabilir. Feokromositoma, MAO inhibitöre bağlı hipertansif aciller ve klonidinin ani kesilmesi gibi katekolamin artışının olduğu durumlarda da etkindir $(9,46)$.

Labetolol $20 \mathrm{mg}$ iV bolus şeklinde başlanabilir. Daha sonra 10 dakikalık aralıklarla $20-80$ mg boluslar şeklinde tasarlanan kan basıncı sağlanana kadar tekrar edilebilir. 20 mg bolus sonrasında, \% 5 Dekstroz çözeltisi içine konularak, 1-2 mg/ saat olacak şekilde iv. infüzyon olarak da verilebi$\operatorname{lir}(1,9,46)$. Ülkemizde bulunmamaktadır.

\section{Esmolol}

Esmolol kardioselektif beta bloker sınıfından bir ilaçtır. Kısa etkilidir, iv verildikten 1-2 dakika içinde etkisi başlar, 10-30 dakika kadar devam eder. Katabolizması böbrek veya karaciğer fonksiyonlarından bağımsızdır eritrositlerdeki esterazlar tarafından yıkılır. $250-500 \mathrm{mcg} / \mathrm{kg}$ iv. bolus 1 dakika içerisinde, sonra $50-100 \mathrm{mcg} / \mathrm{kg} /$ dk iv. infüzyon; her 5 dakikada bir bolus tekrar edilebilir veya infüzyon $300 \mathrm{mcg} / \mathrm{kg} / \mathrm{dk}^{\prime}$ ya kadar artırılabilir. Supraventriküler taşikardilerde, perioperatif hastalardaki $\mathrm{HT}^{\prime}$ da, koroner olaylarda tirotoksikozda ve entübasyona bağlı ani tansiyon yükselmelerinde kullanılmaktadır. Astım ve $\mathrm{KOAH}$ gibi obstrüktif akciğer hastalığı olanlarda ve kokain ilişkili koroner olaylarda kullanılmamalıdır $(1,9,46)$.

\section{Fenoldopam}

Fenoldopam dopamin-1 reseptörleri aracılığı ile periferik vazodilatasyon sağlar. Karaciğerde metabolize edilir. Etkisi 5 dakika içinde başlar, 30 dakika kadar devam eder. Genellikle 0,03-0,1 $\mathrm{mcg} / \mathrm{kg} / \mathrm{dk}$ dozunda başlanır. İv infüzyon kesildiğinde rebaund etkisi yoktur. Ciddi hipertansiyon hastalarında, böbrek hasarı varlığında kreatinin klerensini, idrar çıkışını ve sodyum atılımını iyileştirmektedir $(1,9,46)$. Ülkemizde kullanımda değildir.

\section{Nikardipin}

Nikardipin ikinci nesil dihidropiridin türevi kalsiyum kanal blokeridir. Total PVR'ı azaltarak art yükü azaltırken, kalp üzerinde belirgin negatif inotropik etki göstermez. Koroner ve serebral 
vazodilatör etkisi güçlüdür, subaraknoid kanama sonrasında oluşan serebral vazospazmı azaltır. 5-15 dakika içinde etkisi başlar, yaklaşık 30-40 dakika devam eden etkisi 4 saate kadar uzayabilir. Nikardipin iv uygulandığında kardiyak ve serebral iskemiyi azaltmaktadır. Postoperatif hipertansiyon, kararlı anjina ve konjestif kalp yetmezliği durumlarında kullanılabilmektedir. 5 mg/ saat hızında iv infüzyonla başlanıp 5 dakikada bir $2,5 \mathrm{mg} / \mathrm{saat}$ arttırılarak en fazla $15 \mathrm{mg} / \mathrm{ssaat}$ hızına kadar çıkılabilir $(1,9,46)$. Ülkemizde bulunmamaktadır.

\section{Enalaprilat}

Enalaprilin de-esterifikasyonuyla oluşan biyolojik aktif metabolitidir. Koroner vazodilatasyon yaptığı, OAB düşürdüğü ve pulmoner kapiller basıncını azalttığı için sol ventrikül yetmezliği olan hastalarda etkin olarak kullanılabilir. İntravenöz verildiğinde etkisi 15 dakika içinde başlar 6 saate kadar devam eder. Katabolizmasından böbrekler büyük oranda sorumludur bu nedenle böbrek hasarı olan hastalarda doz ayarı yapılmalıdır. 0,625-1,25 mg iv. bolus olarak 6 saatte bir uygulanır. Ülkemizde bulunmamaktadır (46).

\section{Fentolamin}

Seçici olmayan yarışmalı alfa bloker ilaçtir. Hem $\alpha 1$ hem de $\alpha 2$ eşit affinitesi vardır, bu nedenle ilk dozdan sonra taşikardi sıktır. Feokromasitoma gibi katekolamin yükselmesine bağlı hipertansiyon acillerinde beta bloker tedavisinden önce kullanılabilir. 5-15 mg iv. bolus şeklinde uygulanır. Sürekli bir etki için 0,5-2 mg/dk sürekli iV infüzyon uygulanabilir $(1,49)$.

\section{Hidralazin}

Arteriolar direk etkili vazodilatördür. Etkisi 10 dakika içinde başlar, 4-6 saate kadar devam eder. Kas içi enjeksiyondan sonra 20 dakika içinde, oral alındığında 30 dakika içinde etkisi başlar. Katabolizması karaciğer ve bağırsak duvarlarında asetilasyon ile olur. Bu nedenle, yavaş asetilasyon yapan hastalarda toksik komplikasyonlar görülebilir . İntravenöz yoldan verildiğinde 10-20 mg bolus olarak, kas içi enjeksiyon yolu ile verildiğinde 10-40 mg olarak uygulanır. Uygulanan doz 30 dakikada bir tekrar edilebilir. Hidralazinin en sık kullanım alanı gebeliğe bağlı hipertansiyondur. Aort diseksiyonu veya koroner arter hastalığı olan bireylerde kullanılmamalıdır. Kan basıncında ani düşüşlere neden olması nedeniyle hipertansif acillerde kullanılmamasını öneren çalışmalar vardır(1, 9,46). Ülkemizde yoktur.

\section{Diüretikler}

Hipertansif acillerde basınç ilişkili natriürez'e bağlı gelişen hacim kaybı sık görülür. İntravenöz diüretik uygulaması bu durumu ağırlaştırarak doku iskemisi riskini arttırabilir. Bu nedenle volüm yükü bulguları (pulmoner ödem, kalp yetmezliği gibi) olan hastalar için uygun bir tedavi seçeneğidir (9).

\section{Ağızdan kullanılan ilaçlar}

Daha sıklıkla hipertansif öncelikli(urgency) durumlarda kullanılan ilaçlardır.

\section{Kaptopril}

Ağızdan alındığında hızla emilen, etkisi 15 dakikada başlayarak 4-6 saat süren bir ACE inhibitörüdür. Kalp debisinde, kalp hızında ve serebral kan akımında hiç değişiklik yapmaz. Böbreklerden metabolize olduğu için böbrek yetmezliği olan hastalarda doz azaltılması gerekmektedir. Genel olarak ağızdan 25 mg ile tedaviye başlanır. Doz cevap eğrisi düz olduğu için artan dozlarda verilmesi kan basıncında genellikle daha fazla düşmeye neden olmaz. Hipertansif acil durumların tedavisinde, renovasküler hipertansiyonu olan hastalarda, kalp yetmezliği olan hastalarda oldukça faydalıdır. Bilateral renal arter stenozu olan hastalara, tek taraflı stenozu olan tek böbrekli hastalara böbrek yetmezliği riski nedeniyle verilmemelidir(46).

\section{Nifedipin}

Nifedipin dihidropiridin grubu antihipertansiftir. Ağızdan ve dilaltı olarak hipertansif kriz tedavisinde yaygın olarak kullanılmış, gelişen ani ve kontrolsüz AKB düşmesinin serebral, renal ve kardiyak iskemiyi arttırabildiği görülmüş bu nedenle uzun etkili preperatlar dışında kullanımından vazgeçilmiştir $(1,9,46)$. Uzun etkili preperat- 
ları akut ciddi HT kontrol altına alındıktan sonra idame tedavide güvenli olarak kullanılmaktadır.

\section{Klonidin}

Santral etkilli alfa adrenerjik agonisttir. Plazma katekolamin seviyelerini düşürürken kalp debisinde, böbrek kan akımında ve glomerular filtrasyon hızında değişikliğe neden olmaz. AKB'nı düşürür, kalp hızını azaltır ve sedasyon yapar. Kokain yoksunluğuna bağlı hipertansif acil durumlar için iyi bir seçenektir. Ağızdan 0,1 veya $0,2 \mathrm{mg}$ dozuyla başlanır, toplam doz 0,7 mg oluncaya kadar her saat tekrarlanabilir. Yüksek doz klonidin kullanımının ani olarak bırakılması sonrası ciddi rebaund $\mathrm{HT}$, flushing ve abdominal semptomlar görülebilir (46).

\section{REFERANSLAR}

1. James PA, Oparil S, Carter BL, Cushman WC, DennisonHimmelfarb C, Handler J et al. 2014 evidence-based guideline for the management of high blood pressure in adults: report from the panel members appointed to the Eighth Joint National Committee (JNC 8). JAMA. 2014 Feb 5;311(5):507-20.

2. Mancia G, Fagard R, Narkiewicz K, Redón J, Zanchetti A, Böhm M et al. 2013 ESH/ESC Guidelines for the management of arterial hypertension: the Task Force for the management of arterial hypertension of the European Society of Hypertension (ESH) and of the European Society of Cardiology (ESC). J Hypertens. 2013 Jul;31(7):1281-357.

3. Jaques $\mathrm{H}$; National Institute for Health and Clinical Excellence (NICE). NICE guideline on hypertension. Eur Heart J. 2013 Feb;34(6):406-8.

4. Dasgupta K, Quinn RR, Zarnke KB, Rabi DM, Ravani P, Daskalopoulou SS et al. The 2014 Canadian Hypertension Education Program recommendations for blood pressure measurement, diagnosis, assessment of risk, prevention, and treatment of hypertension. Can J Cardiol. 2014 May;30(5):485-501.

5. Arıcı M, Birdane A, Güler K,Yıldız BO, Altun B, Ertürk Ş, Aydoğdu S, Özbakkaloğlu M, Ersöz HÖ, Süleymanlar G, Tükek T,Tokgözoğlu L, Erdem Y,Türk Kardiyoloji Derneği (TKD), Türk İç Hastalıkları Uzmanlık Derneği (TiHUD),Türkiye Endokrinoloji ve Metabolizma Derneği (TEMD), Türk Nefroloji Derneği (TND),Türk Hipertansiyon ve Böbrek Hastalıkları Derneği.Türk hipertansiyon uzlaşı raporu. (Turkish hypertension consensus report) Türk Kardiyol Dern Arş - Arch Turk Soc Cardiol 2015;43(4):402-409

6. Ahmed MEK, Walker JM, Beevers D6, Beevers M. Lack of difference between malignant and accelerated hypertension. Br. Med J 1986; 292: 235-237.

7. Egan BM, Zhao Y, Axon RN. US trends in prevalence, awareness, treatment, and control of hypertension, 1988-2008. JAMA 2010; 303:2043

8. Altun B, Arici M, Nergizoğlu G, Derici U, Karatan O, Turgan C, Sindel S, Erbay B, Hasanoğlu E, Cağlar S; for the Turkish Society of Hypertension and Renal Diseases. Prevalence, awareness, treatment and control of hypertension in Turkey (the PatenT study) in 2003. Journal of Hypertension. 2005;23:1817-1823.

9. Marik PE, Varon J. Hypertensive crises: challenges and management. Chest. 2007;131:1949-62. (4)

10. Frank, M; Bobrie, G; Azizi, M; Peyrard, S; Plouin, PF. Clinical Profile of Patients Referred to A Tertiary Hypertension Unit in A City Area. Journal of Hypertension. June 2010, 28:e264.

11. Slama M, Modeliar SS Hypertension in the intensive care unit. Curr Opin Cardiol. 2006 Jul;21(4):279-87.

12. Halpern NA, Goldberg M, Neely C, et al. Postoperative hypertension: a multicenter, prospective, randomized comparison between intravenous nicardipine and sodium nitroprusside. Crit Care Med 1992; 20:16371643.

13. Prys-Rroberts $\mathrm{C}$. Anaesthesia and hypertension. $\mathrm{Br} \mathrm{J}$ Anaesth 1984;56:711-724

14. Toraman F, Karabulut H, Goksel O, et al. Comparison of antihypertensives after coronary artery surgery. Asian Cardiovasc Thorac Ann 2005; 13:302-306.

15. Which anticonvulsant for women with eclampsia? Evidence from the Collaborative Eclampsia Trial. Lancet 1995; 345:1455-1463.

16. Briones-Garduno JC, Gomez-Bravo Topete E, AvilaEsquivel F, Diaz de Leon-Ponce M. TOLUCA experience in preeclampsia-eclampsia [in Spanish]. Cir Cir 2005; 73:101-105.

17. Lucas MJ, Leveno KJ, Cunningham FG. A comparison of magnesium sulfate with phenytoin for the prevention of eclampsia. N Engl J Med 1995; 333:201-205.

18. Kitiyakara C, Guzman NJ. Malignant hypertension and hypertensive emergencies.J Am Soc Nephrol 1998; 9:133-142.

19. Guyton AC, Coleman TG, Cowley AW, Scheel KW, Manning RD, Norman RA. Overriding dominance of the kidneys in long-term regulation and in hypertension. Am J Med. 1972; 52: 5; 584-594. 
20. Strandgaard S, Paulson OB. Cerebral blood flow and its pathophysiology in hypertension. Am J Hypertens 1989; 2:486.

21. Varon J, Strickman NE. Diagnosis and treatment of hypertensive crises in the elderly patients. J Geriatr Cardiol 2007;4:50-55.

22. Vaughan CJ, Delanty N. Hypertensive emergencies. Lancet 2000;356:411-7

23. Cherney D, Straus S. Management of patients with hypertensive urgencies and emergencies: a systematic review of the literature. J Gen Intern Med 2002; 17:937.

24. Zeller KR, Von Kuhnert L, Matthews C. Rapid reduction of severe asymptomatic hypertension. A prospective, controlled trial. Arch Intern Med 1989; 149:2186.

25. O'Mailia JJ, Sander GE, Giles TD. Nifedipine-associated myocardial ischemia or infarction in the treatment of hypertensive urgencies. Ann Intern Med 1987; 107:185.

26. Grossman E, Messerli FH, Grodzicki T, Kowey P. Should a moratorium be placed on sublingual nifedipine capsules given for hypertensive emergencies and pseudoemergencies? JAMA 1996; 276:1328.

27. Prêtre R, Von Segesser LK. Aortic dissection. Lancet 1997; 349:1461. (5)

28. Wijdicks EF, Sheth KN, Carter BS, Greer DM, Kasner SE, Kimberly WT et al. Recommendations for the management of cerebral and cerebellar infarction with swelling: a statement for healthcare professionals from the American Heart Association/American Stroke Association. Stroke. 2014 Apr;45(4):1222-38.

29. Adams HP Jr, del Zoppo G, Alberts MJ, et al. Guidelines for the early management of adults with ischemic stroke. Stroke 2007; 38:1655

30. National Institute for Health and Clinical Excellence. Stroke: The diagnosis and acute management of stroke and transient ischaemic attacks. Royal College of Physicians, London 2008.

31. Hemphill JC 3rd, Greenberg SM, Anderson CS, Becker K, Bendok BR, Cushman M et al. Guidelines for the Management of Spontaneous Intracerebral Hemorrhage: A Guideline for Healthcare Professionals From the American Heart Association/American Stroke Association. Stroke. 2015 May 28.

32. Broderick J, Connolly S, Feldmann E, et al. Guidelines for the management of spontaneous intracerebral hemorrhage in adults: 2007 update. Stroke 2007; 38: 2001.

33. Schmidt JM, Ko SB, Helbok R, et al. Cerebral perfusion pressure thresholds for brain tissue hypoxia and metabolic crisis after poor-grade subarachnoid hemorrhage. Stroke 2011; 42:1351.

34. Van Gijn J. Subarachnoid haemorrhage. Lancet 1992; 339:653.

35. Jeffrey L. Anderson, Cynthia D. Adams, Elliott M. Antman, Charles R. Bridges, Robert M. Califf, Donald E. Casey, Jr., William E. Chavey II, Francis M. Fesmire,
Judith S. Hochman, Thomas N. Levin, A. Michael Lincoff, Eric D. Peterson, Pierre Theroux, Nanette Kass Wengerand R. Scott Wright. ACC/AHA 2007 Guidelines for the Management of Patients With Unstable Angina/Non-ST-Elevation Myocardial Infarction: Executive Summary. Circulation. 2007;116:803-877.

36. Kaplan, NM. Hypertensive crises. In: Kaplan's Clinical Hypertension, 9th ed, Neal, W (Ed), Lippincott, Williams and Wilkins, Baltimore 2006. p.311.

37. Visintin C, Mugglestone MA, Almerie MQ, et al. Management of hypertensive disorders during pregnancy: summary of NICE guidance. BMJ 2010; 341:c2207.

38. Sibai BM. Chronic hypertension in pregnancy. Obstet Gynecol 2002; 100:369.

39. Duley L, Henderson-Smart DJ, Meher S. Drugs for treatment of very high blood pressure during pregnancy. Cochrane Database Syst Rev 2006; :CD001449.

40. Committee on Obstetric Practice. Committee Opinion no. 514: emergent therapy for acute-onset, severe hypertension with preeclampsia or eclampsia. Obstet Gynecol 2011; 118:1465.

41. Houston MC. Abrupt cessation of treatment in hypertension: consideration of clinical features, mechanisms, prevention and management of the discontinuation syndrome. Am Heart J 1981; 102:415.

42. Miller RR, Olson HG, Amsterdam EA, Mason DT. Propranolol-withdrawal rebound phenomenon. Exacerbation of coronary events after abrupt cessation of antianginal therapy. N Engl J Med 1975; 293:416.

43. Prichard BN, Ross EJ. Use of propranolol in conjunction with alpha receptor blocking drugs in pheochromocytoma. Am J Cardiol 1966; 18:394.

44. Brown H, Goldberg PA, Selter JG, et al. Hemorrhagic pheochromocytoma associated with systemic corticosteroid therapy and presenting as myocardial infarction with severe hypertension. J Clin Endocrinol Metab 2005; 90:563.

45. Krukemyer JJ, Boudoulas H, Binkley PF, Lima JJ. Comparison of hypersensitivity to adrenergic stimulation after abrupt withdrawal of propranolol and nadolol: influence of half-life differences. Am Heart J 1990; 120:572.

46. Wu MM, Chanmugam A: Hypertension. In Tintinalli JE, Kelen GD,Stapczynski JS (eds): Emergency Medicine A Comprehensive Study Guide. 6th ed. New York: The Mc Graw Hill Companies, 2003, Sayfa:394- 404.

47. Robin ED, McCauley R. Nitroprusside-related cyanide poisoning: time (long past due. for urgent, effective interventions: Chest 1992; 102:1842-1845.

48. Friederich JA, Butterworth JF. Sodium nitroprusside: twenty years and counting. Anesth Analg 1995;81: 152-162.

49. Santhi R, Worthley LIG. Hypertension in the Critically III Patient. Critical Care and Resuscitation 2003; 5: 24-42. 